\title{
ららみんノ抗體產生二及ボス影響 (第1回報告)
}

ららみん八凝集價二及ボ ス影響併二

同哑二ヨル中毒賓血卜凝集素產生卜

,關係二就テ

宗都帝國大學䝂學部微生物學教豈 (主任: 清野数授)

醫學士 田原留吉

\section{目次}

緒諭

實教方法

第1章 正常㠜集素/䈓合

第2章 免选凝集素新生, 埸含

第3章 既生免没疑集素／程合

總 括

結 諭

交献

緒

論

ちらみんノ樂物學的作用二關シ $テ 、 ， 1909$ 年 Bagor u Dale $e_{(1)}$ ガ麥角ノ水製

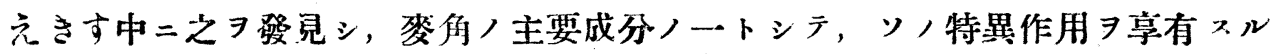
モノナリト唱導セショリ, 研究業績續出シ殆ドソノ詳細 倘, 學者ニョリ多少意見八相違ナキ能ハズ. 即, ちらみんハソ, 化學的構造 $\mathrm{OH} \longrightarrow \mathrm{CH}_{2} \mathrm{CH}_{2} \mathrm{NH}_{2}$ 二於テあごれなりん類似セルガ如ク，其作用二於テモ 又交感神經刺戟劑トシテ，兩者ノ間二多ク/共通點 (Dale u Dixon (2) Knaffl-Lenz u Pick(3) ) ナホ, 嚴密二之ヨ精査七バ, ソノ作用機 轉少シク異ルモノ, 如シ, (Baehr u. Pick,,$_{(4)}$ Barbour,,$_{(5)}$ Handousky u. Pick,(6) Hilz $_{(7)}$ 富永 $(8)$ 近藤 $(9)$ ).

暴二 Berthelot u. Bertrand $(10)$ 八, 人間, 膓内容ヨリ分離セシ Bac. Pneumoniae Friedländer 二屬セルー種ノ細菌ニョリテ, 次デ佐々木氏 
(1538)

ヨリテ, らみんガち万ぢんョワ多量二分解サル、コトヨ報告セリ。サレバた らみんく之等ノ細菌ニョル蛋白分解產出物トシテ, 動物ノ膓管內二自然二生成 セラル可ク，更二本劑ガ消化管粘膜ヨリ吸收セラレ充分ニソノ藥物學的作用 $\ni$ 發揮シ得ルコトハ, Dale u. Dixon(12) ガ自家實驗ニヨシテ漞シク證明セル處ナ y. 由是觀之, ちらみん八動物ノ生理的作用二對シ重大ナル關係习有スルモノ ナルベク，從テソノ苼疫上二字ボス影響如何》實二興味深キ問題ナラズト七 ズ.

而シテ本劑卜類似ノ作用ヨ有スルあごれなりんノ抗體產生二及ボス效果二就 テハ, Borclaard $_{(13)}$ ガちふす患者二之ヨ應用セショ!ソノ報告少カラズト雖モ, ちらみん二關スル這般ノ研究二至リテハ, 未ダ之アルヨ知ラズ.

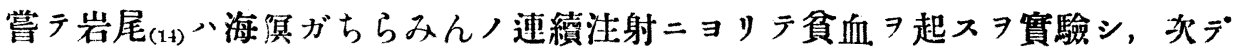
同氏 $(15)$ 家鬼 $=$ 於テモソノ大量使用ニョリ强度ノ貧血 $ヨ$ 招來シ，檢鏡上身體諸 種ノ臟器二顯著ナル Siderosis ヨ認メタリト報ジ, ナホ高森(16) モ又家兔二於テ 同樣ナル實驗ヨ試ミタリ，即ちらみんハ一程ノ血液毒ナル可シ。而シテ程々ノ 血液毒 $=コ ル$ 實驗的中毒貧血ノ自然免疫性及抗體產生ノ上二及ボス影響二就テ 八, 其ノ交献二乏シク而モ學者二ヨリ多少意見 $ヨ$ 異二ス (Mya u. Sanarelli ${ }_{(17)}$ Martels $_{(18)}$ Lüdke u.Körber $(19)$ ).

余ハららみん注射ガ家兔ノ正常抗體，既生免疫抗體及㣻疫抗體產生二及ボス 影響, 升二本劑ニョル中毒貧血卜抗體產生卜ノ關係二就キ研究シ, 聊力得ル處 アリタルョ以テ左二其ノ梗概 7 記迹ス可シ.

\section{䔈 驗 方 法}

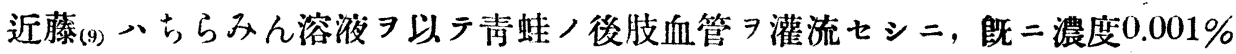

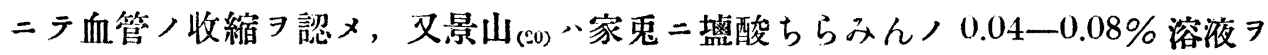
徐タ 注射セル二血壓上杽及糖尿 來シ，更二大量 7 注射スレバ顯著ナル血糖

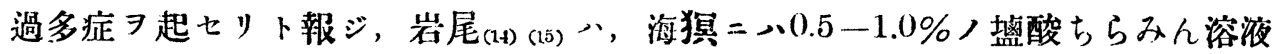

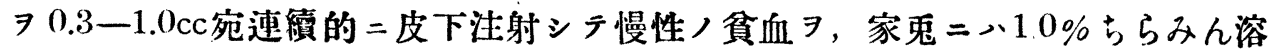
液 $79.0 \mathrm{cc}$ 宛1日2回, 5 日間, 靜脈内注射シテ强度ノ急性賓血习起七リト報ビリ. 余入ちらみ九 (武田) $70.5-1.0 \%$ 割 $=0.9 \%$ 食盍水 $\ni$ 以テ溶解シ，常ニンノ5.0 
-10.0cc 71 回量トシテ靜脈內二注射セり.

又筫驗動物トシテ、體重 $2 \mathrm{Kg}$.前後ノ健康ナル成熟家兔 $ヨ$ 選ビ、體重ニヨル注 射量/補正八, 餘リ二煩椎ナルヨ以テ之ヨ省略セリ。

㣻疫元トシテハ七ふす菌(土谷株) ヨ用七, 該菌ノ20時間, 寒天斜面培養一白

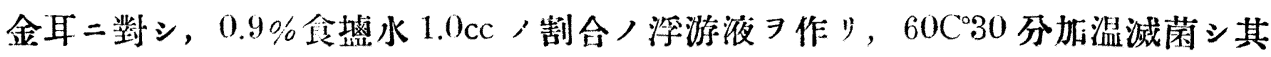
>0.5-1.0mg 7 家鬼,耳静脈內二注射七り.

血清凝集價ノ测定二メ，可檢血清 $\ni$ 生理的食㙳水ニテ順次稀釋シ，ソノ各0.5 $\mathrm{cc}$ 二前記菌浮游液 $0.5 \mathrm{cc}$ 加へ, $37^{\circ} \mathrm{C}=$ 置クコト2時間, 後室温二放置シテ翌朝 ソノ凝集價ヨ檢セリ.

ナホ檢血二八早朝, 家鬼ノ空腹時 $习$ 選ビ Thoma-Zeiss ノ血球計算器及 Sahli 八血色素計 $\exists$ 使用七リ。

\section{第 1 章 正常凝集素ノ德合}

顗ノ家鬼二ちらみんノ0.5\% 溶液 $5 \mathrm{cc}$ 宛 7 隔日 就キ凝集價 $\ni$ 檢セリ.

第 1 表

\begin{tabular}{|c|c|c|c|c|c|c|c|c|c|c|c|c|c|c|c|c|}
\hline 家 兔 番 號 & \multicolumn{2}{|c|}{ 第3.敩虎 } & 觶重 & \multicolumn{5}{|c|}{$\begin{array}{l}2.000 \mathrm{Kg} . \\
\text { 隔 } \mathrm{H} 0.5 \% \text { cc宛 }\end{array}$} & \multicolumn{8}{|c|}{$\begin{array}{ll}\text { 第4號體重 } & 2.150 \\
\text { 注射 } & \text { 同航 }\end{array}$} \\
\hline 試驗管番號 & 1 & 2 & 3 & 4 & 5 & 6 & 7 & 8 & 1 & 2 & 3 & 4 & 5 & 6 & 7 & 8 \\
\hline 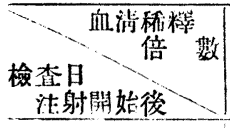 & 10 & 20 & 40 & 80 & 160 & 320 & 640 & $\mathrm{~K}$ & 10 & 20 & 40 & 80 & 160 & 320 & 640 & $\mathrm{~K}$ \\
\hline 注 射 前 & + & + & - & - & - & - & - & - & + & + & \pm & - & - & -1 & - & - \\
\hline 第 31$]^{\text {注射回數 }}$ & HH & H & $H$ & + & + & + & - & - & $H$ & $H$ & + & + & + & - & - & - \\
\hline 第 7 日 3 回 & H & H & + & $T$ & + & + & - & - & H & $H$ & $H$ & + & + & \pm & - & - \\
\hline 第 10 日 5 回 & H & $H$ & + & + & - & - & - & - & $H$ & + & + & + & + & - & - & - \\
\hline 第 14 日 7 间 & H & $H$ & + & + & \pm & - & - & - & $H$ & + & + & - & - & - & - & - \\
\hline 第 17 日 8 回 & $H$ & + & + & + & + & - & - & - & + & + & \pm & - & - & - & - & - \\
\hline 第 21 日 10 回 & $H$ & + & + & + & \pm & - & - & - & + & + & + & + & - & - & - & - \\
\hline 第 24 日 12 问 & $H$ & + & + & + & - & - & - & - & + & + & + & + & - & - & - & - \\
\hline 第 28 日 14 回 & $H$ & + & + & + & - & - & - & - & + & + & + & + & - & - & - & - \\
\hline 第 31 日 15 回 & + & + & + & + & - & -- & - & - & + & + & + & \pm & - & -1 & - & - \\
\hline 第 35 日 17 回 & + & + & \pm & - & - & - & - & - & + & + & + & \pm & - & -1 & - & - \\
\hline
\end{tabular}




\begin{tabular}{|c|c|c|c|c|c|c|c|c|c|c|c|c|c|c|c|c|}
\hline 家 鬼 番 號 & \multicolumn{2}{|c|}{ 第可號 } & $\begin{array}{l}\text { 體重 } \\
\text { 注射 }\end{array}$ & \multicolumn{5}{|c|}{$\begin{array}{l}2.100 \mathrm{Kg} \text {. } \\
\text { 隔日 } 0.5 \% 5 \mathrm{cc} \text { 宛 }\end{array}$} & \multicolumn{8}{|c|}{$\begin{array}{ll}\text { 第6 號 體重 } & 2.000 \\
\text { 注间前 }\end{array}$} \\
\hline 試 噞管 番 號 & 1 & 2 & 3 & 4 & 5 & 6 & 7 & 8 & 1 & 2 & 3 & 4 & 5 & 6 & 7 & 8 \\
\hline $\begin{array}{l}\text { 血清稀釋 } \\
\text { 檢查日 } \\
\text { 汁射留始後 }\end{array}$ & 10 & 20 & 40 & 80 & 160 & 320 & 640 & $\mathrm{~K}$ & 10 & $\therefore 0$ & 40 & 80 & 160 & $3 \simeq 0$ & 640 & $\mathrm{~K}$ \\
\hline 注 射 前 & + & + & + & - & - & - & - & - & + & + & - & - & - & - & - & - \\
\hline 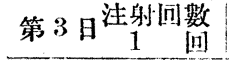 & H & H & $H$ & + & + & + & - & - & $H$ & $H$ & + & + & + & \pm & - & - \\
\hline 第 7 日 3 回 & $\mathrm{H}$ & H & H & + & + & + & - & - & $\mathrm{Ht}$ & $H$ & H & + & + & + & - & - \\
\hline 第 10 日 5 回 & Ht & $H$ & $H$ & + & + & + & - & - & $H$ & + & + & + & - & 一 & $\cdots$ & - \\
\hline 第 14 日 7 回 & H & H & + & + & + & \pm & - & - & $H$ & + & + & + & + & - & - & - \\
\hline 第 17 日 8 回 & H' & $H$ & + & + & + & - & - & - & $H$ & + & + & + & + & - & - & - \\
\hline 第 21 日 10 回 & H & $H$ & + & + & + & - & - & - & + & + & + & + & - & $\cdots$ & $\cdots$ & $\cdots$ \\
\hline 第 24 日 12 回 & $H$ & + & + & + & 一 & - & - & - & + & + & + & - & - & - & - & - \\
\hline 第 28 日 14回 & + & + & + & - & - & - & - & - & + & + & + & - & - & - & - & - \\
\hline 第 31 日 15回 & + & + & \pm & $\cdots$ & - & 一 & - & - & + & + & + & \pm & - & - & - & - \\
\hline 第 35 日 17问 & + & + & \pm & - & - & - & - & - & + & + & $\ldots$ & $\ldots$ & $\ldots$ & - & - & $\cdots$ \\
\hline
\end{tabular}

第1表 $\exists$ 觀ルニ, ちふす菌二對スル家兔ノ正常凝集價八, ちらみん1回ノ泩射 ニョリテ(第只日）20-40倍ョリ一躍，160一320倍二上昇云，更二注射 7 繼續

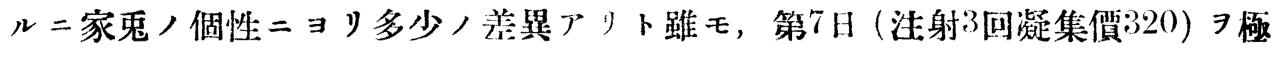
期トシテ徐々 二低减シ， 2 週間二テ 160 倍前偻二，3週間二テハ約 80 倍二，4週間

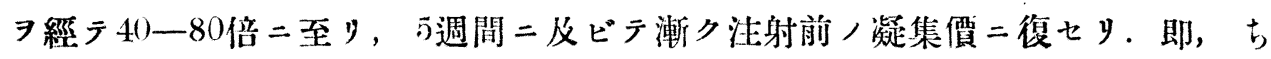
らみんノ注射ハ家兔ニ於ヶル正常凝集價习著ク昂進セシムルモ, 之ヨ連續入レ バ逐ニソノ作用 7 失フモノナリ。

\section{第 2 章 免疫凝集素新生ノ舓合}

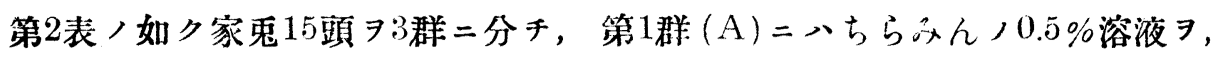

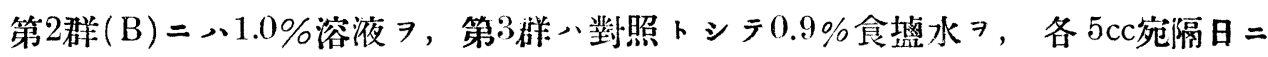

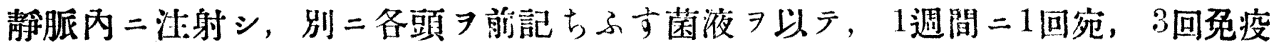
シ每免疫挠 1 週間 7 經テ探血シ, ソノ血清二就キ凝集價 7 測定セリ 
H 原 留 吉 述 (1541)

第 2 表

\begin{tabular}{|c|c|c|c|c|c|c|c|c|c|c|}
\hline & \multirow[b]{2}{*}{ 椺查 } & \multirow[b]{2}{*}{ 象西番號 } & 試驗管番號 & \multirow{2}{*}{$\begin{array}{l}1 \\
5\end{array}$} & \multirow{2}{*}{2} & \multirow{2}{*}{$\begin{array}{c}3 \\
20\end{array}$} & \multirow{2}{*}{$\begin{array}{c}4 \\
30\end{array}$} & \multirow{2}{*}{$\frac{5}{40}$} & \multirow{2}{*}{$\begin{array}{r}6 \\
50\end{array}$} & \multirow{2}{*}{$\frac{7}{60}$} \\
\hline & & & 血涼稀 & & & & & & & \\
\hline \multirow{3}{*}{ 健 } & \multirow{4}{*}{$\tilde{j}$} & 第 8 號 & 1950 & + & + & + & - & - & - & - \\
\hline & & 第 9 號 & 2150 & + & + & + & + & + & - & - \\
\hline & & 管 10 號 & 1950 & + & + & + & + & - & - & 一 \\
\hline 常 & & 第 11 號 & 2000 & + & + & + & - & -- & - & - \\
\hline \multirow[t]{2}{*}{ 血 } & \multirow{3}{*}{ H } & 第 12 號 & 2100 & + & + & + & - & - & - & - \\
\hline & & 第 13 號 & 2000 & + & + & \pm & - & $\cdots$ & - & - \\
\hline 清 & & 第 14 號 & 2100 & + & + & + & - & - & - & - \\
\hline 菌 & \multirow{3}{*}{6} & 第 15 號 & 1950 & + & + & + & - & - & - & 一 \\
\hline \multirow[t]{2}{*}{ 凝 } & & 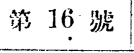 & 2050 & + & + & + & + & 一 & - & - \\
\hline & & 籍 17 號 & 2000 & + & + & + & + & - & - & $\cdots$ \\
\hline 菒 & \multirow{5}{*}{ H } & 第 19 號 & 2100 & + & + & + & + & + & - & - \\
\hline \multirow[t]{2}{*}{ 仪 } & & 第 20 號 & 1900 & + & + & $+i$ & + & $\cdots$ & - & - \\
\hline & & 第 21 號 & 1950 & + & + & + & + & + & - & - \\
\hline & & 第 22 號 & 2000 & + & + & + & \pm & - & - & - \\
\hline & & 第 23 號 & 1900 & + & + & + & \pm & - & - & - \\
\hline
\end{tabular}

\section{第 3 表}

\begin{tabular}{|c|c|c|c|c|c|c|c|c|c|c|c|c|c|c|c|c|c|c|c|c|}
\hline \multirow{2}{*}{$\begin{array}{l}\text { 免设 } \\
\text { 回次 }\end{array}$} & \multicolumn{2}{|c|}{ 檢沝 } & & & 訪驗管番號 & 1 & 2 & 3 & 4 & $\tilde{5}$ & 6 & 7 & 8 & 9 & 10 & 11 & 12 & 13 & 14 & 15 \\
\hline & \multicolumn{2}{|c|}{ 月日 } & 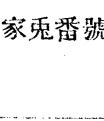 & a & $\begin{array}{c}\text { 血㳹稀 } \\
\text { 䅸倍數 } \\
\text { 注射量 }\end{array}$ & 8 & $\mid \begin{array}{l}1 \\
0\end{array}$ & $\frac{1}{8}$ & $\frac{1}{8}$ & $\overbrace{0}^{3}$ & $\frac{1}{8}$ & $\frac{1}{8}$ & $\frac{1}{8}$ & $\frac{210}{8}$ & 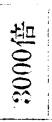 & 迎 & $\begin{array}{l} \pm n \\
0 \\
0 \\
0\end{array}$ & 逝 & 뭉 & 迎 \\
\hline \multirow{5}{*}{$\begin{array}{l}\text { 第 } \\
1 \\
\text { 回 } \\
\text { 免 } \\
\text { 染 } \\
\text { 菌 } \\
\text { 凝 } \\
\text { 集 } \\
\text { 應 }\end{array}$} & \multirow{4}{*}{\begin{tabular}{l|}
5 \\
月 \\
13
\end{tabular}} & \multirow{5}{*}{$\begin{array}{l}\text { 試 } \\
\text { 驗 } \\
\text { 家 } \\
\text { 兔 } \\
\widehat{A}\end{array}$} & 第 8 衤 & 1980 & \multirow{5}{*}{$\begin{array}{l}\text { 隔 日 每 } \\
0.5 \% 5 \mathrm{cc} \\
\text { 宛 }\end{array}$} & H & $H$ & Ht & H & $H$ & H & + & + & + & + & + & + & + & \pm & \\
\hline & & & 第 9 號 & $2: 00$ & & & $\mathrm{H}$ & $H$ & ti & $H$ & + & + & + & + & + & + & - & - & - & - \\
\hline & & & 第10號 & 1950 & & & $\mathrm{HH}$ & $H$ & $H$ & $H$ & $H$ & $H$ & + & + & + & + & + & - & - & 一 \\
\hline & & & 第11號 & 2050 & & & $H$ & $H$ & $H$ & + & + & + & + & + & + & + & + & - & - & - \\
\hline & & & 第12號 & 2100 & & & & & $H$ & H & + & + & + & + & + & \pm & - & - & - & - \\
\hline
\end{tabular}




\begin{tabular}{|c|c|c|c|c|c|c|c|c|c|c|c|c|c|c|c|c|c|c|c|c|}
\hline & & & & & & 1 & 2 & 3 & 4 & 5 & 6 & 7 & 8 & 9 & 10 & 11 & 12 & 13 & 14 & 15 \\
\hline & & & & & 注 & 8 & 进 & $\frac{1}{3}$ & $\frac{1}{3}$ & $\begin{array}{l}\text { 迦 } \\
\text { 吕 } \\
10\end{array}$ & $\begin{array}{l}\text { 迎 } \\
8 \\
0\end{array}$ & $\frac{1}{8}$ & 势 & 逝 & 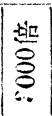 & 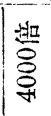 & 装 & $\mid$ & 垫 & $\frac{1}{8}$ \\
\hline \multirow{5}{*}{$\begin{array}{l}\text { 第 } \\
1 \\
\text { 回 } \\
\text { 免 }\end{array}$} & \multirow{3}{*}{5} & \multirow{5}{*}{$\begin{array}{l}\text { 試 } \\
\text { 驗 } \\
\text { 家 } \\
\text { 鬼 } \\
\text { B }\end{array}$} & & & \multirow{5}{*}{$\begin{array}{l}\text { 隔日每 } \\
1.0 \% 5 c c\end{array}$} & & $H$ & $H$ & + & + & + & \pm & - & - & - & - & - & - & -1 & - \\
\hline & & & & 2150 & & $H$ & $|H|$ & $H$ & $1+$ & $1+$ & $1+$ & $1+$ & $1-$ & $1-$ & -1 & - & - & -1 & -1 & $1-$ \\
\hline & & & 第15號 & 2000 & & H & $H$ & $H$ & $H$ & + & + & $1+$ & $1+$ & \pm & $1-$ & - & $1-$ & $1-1$ & -1 & - \\
\hline & \multirow[t]{2}{*}{ 月 } & & & 2100 & & H & $H$ & $H$ & + & + & + & + & + & - & - & $1-$ & $1-$ & - & -1 & - \\
\hline & & & & 2050 & & 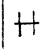 & $H$ & + & + & 1 & $1+$ & + & + & - & - & $1-$ & - & -1 & -1 & $1-$ \\
\hline \multirow{3}{*}{ 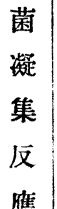 } & \multirow[t]{2}{*}{13} & \multirow{3}{*}{$\begin{array}{l}\text { 對 } \\
\text { 照 } \\
\text { 家 }\end{array}$} & & 2100 & \multirow{5}{*}{$\begin{array}{l}\text { 隔日筆 } 0 . \\
9 \% \text { 食荿 } \\
\text { 水 } 5 \mathrm{cc} \text { 宛 }\end{array}$} & & 141 & 11 & H & $H$ & + & + & + & $1+$ & - & $1-$ & - & - & -1 & - \\
\hline & & & & & & $H$ & $1+1$ & $H$ & $H$ & + & + & + & $1+$ & $1 \pm$ & $1-$ & $1-$ & - & -1 & $1-1$ & $1-$ \\
\hline & & & & & & $\mathrm{HI}$ & $H$ & & $H$ & $H$ & + & $1+$ & + & + & + & $1-$ & $1-$ & - & -1 & $1-$ \\
\hline & & \multirow{2}{*}{ 兔 } & & & & H & $H$ & & $H$ & $1+$ & $1+$ & + & 1 & + & $1-$ & - & - & - & $|-|$ & - \\
\hline & & & & & & & & & & 11 & $i \pi$ & + & + & + & + & - & - & - & - & - \\
\hline
\end{tabular}

第3表 $ᄏ$ 觀ルニ，對照家兔ノ凝集價ハ2000—3000倍ナルニ，第1群ニアリテハ 4000一5000倍二及ビ，殊二家鬼第 8 號，如キ>8000倍ノ稀釋ニ於テスラ凝集反

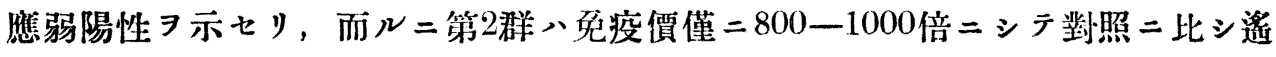
二低位ニアリ，即第 1 回乔疫ニアリテ、ちらみんノ少量注射入凝集素ノ新生 助長セシムルモ, 大量 $ヨ$ 用フレバ却テ阻害セシムルモノナリ。

第 4 表

\begin{tabular}{|c|c|c|c|c|c|c|c|c|c|c|c|c|c|c|c|c|c|c|}
\hline & & & & & & \begin{tabular}{l|l|l|}
1 & 2 & 3
\end{tabular} & $t$ & is & 6 & 7 & 8 & & $1_{0}$ & 11 & 12 & 13 & 14 & \\
\hline & 月日 & & & & 数 & 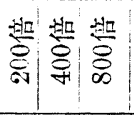 & $\stackrel{1}{8}$ & $\mid$ & $\begin{array}{l}1+1 \\
0 \\
8 \\
0\end{array}$ & $\frac{1}{8}$ & 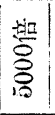 & $\mid$ & $\begin{array}{l}\text { 迦 } \\
\text { } \\
\text { ᄋ }\end{array}$ & $\begin{array}{l}0 \\
0 \\
0 \\
0\end{array}$ & 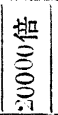 & $\mid$ & $\begin{array}{l}\text { 势 } \\
\vdots \\
0 \\
0 \\
\vdots\end{array}$ & 唯 \\
\hline \multirow{5}{*}{ 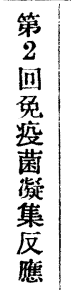 } & \multirow{5}{*}{$\begin{array}{c}5 \\
\text { 月 } \\
20 \\
\text { 日 }\end{array}$} & \multirow{5}{*}{$\begin{array}{l}\text { 試 } \\
\text { 驗 } \\
\text { 家 } \\
\text { 鬼 } \\
\widehat{A}\end{array}$} & & & \multirow{5}{*}{ 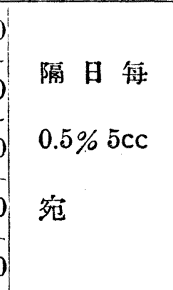 } & $\mathrm{HH} \mathrm{HH}$ & $H$ & $\mathrm{HH}$ & Hi & $\mathrm{H}$ & it & $H$ & + & + & + & +1 & -1 & - \\
\hline & & & & & & $\mathrm{H} H \mathrm{H}$ & $H$ & $H$ & $H$ & + & + & +1 & + & -1 & $1-$ & -1 & -1 & - \\
\hline & & & & & & $H|H| H \mid$ & $\mathrm{Ht}$ & $H$ & $H$ & $H$ & $1+1$ & + & + & + & +1 & - & - & - \\
\hline & & & & 2020 & & $\mathrm{HI}|\mathrm{H}| \mathrm{H} \mid$ & $\mathrm{H}$ & $\mathrm{HI}$ & $H$ & $H$ & + & +1 & + & \pm & $1-$ & -1 & - & - \\
\hline & & & & & & 冊 & Ht & $H$ & H & + & + & + & 1 & - & -1 & - & -1 & \\
\hline
\end{tabular}




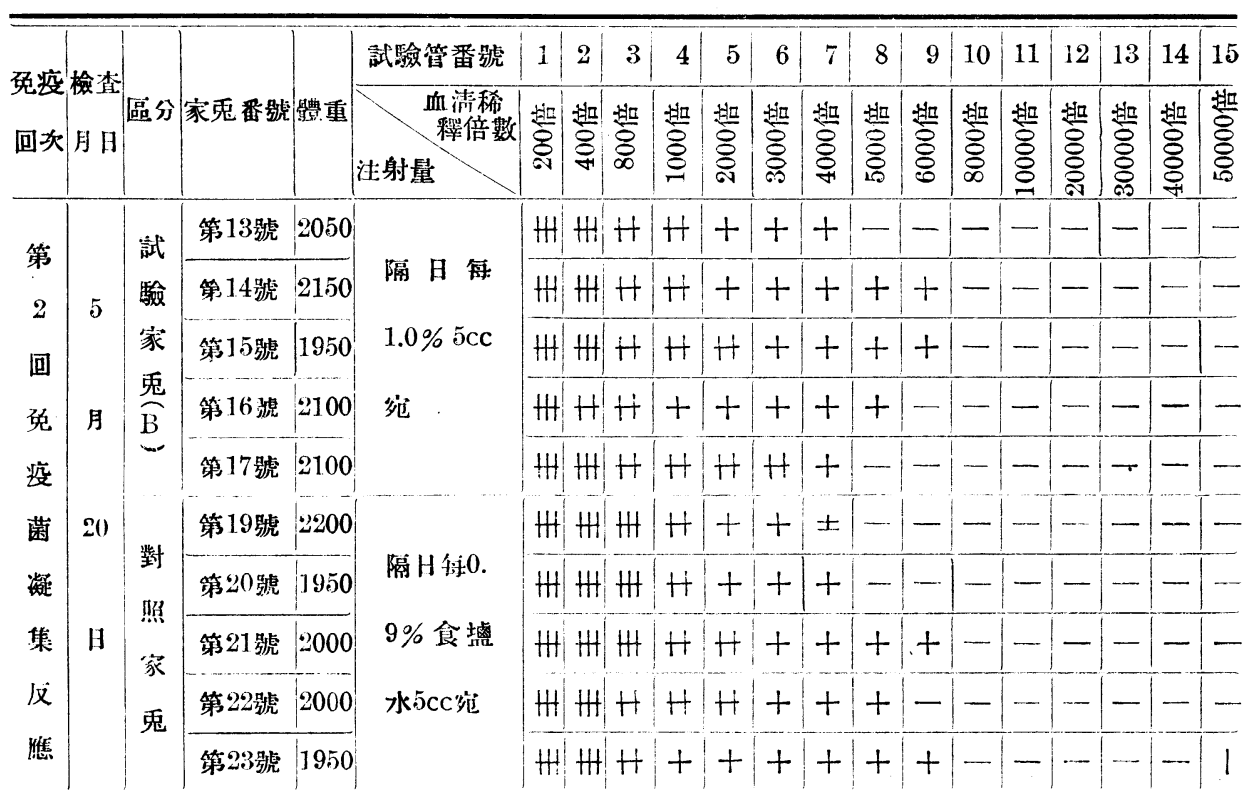

第 5 表

\begin{tabular}{|c|c|c|c|c|c|c|c|c|c|c|c|c|c|c|c|c|c|c|c|c|}
\hline \multirow[b]{2}{*}{ 回次 } & & & \multirow[b]{2}{*}{ 家鬼番號 } & \multirow[b]{2}{*}{ 澧重 } & \multirow{2}{*}{ 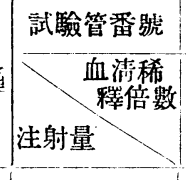 } & \multirow{2}{*}{ 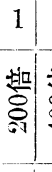 } & \multirow{2}{*}{ 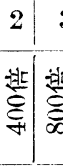 } & \multirow{2}{*}{\multicolumn{2}{|c|}{ 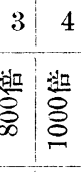 }} & \multirow{2}{*}{ 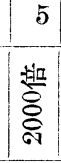 } & \multirow{2}{*}{ 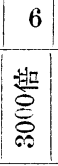 } & \multirow{2}{*}{ 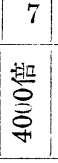 } & \multirow{2}{*}{\begin{tabular}{c|}
8 \\
迎 \\
\\
0 \\
0
\end{tabular}} & \multirow{2}{*}{ 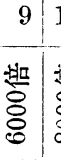 } & \multirow{2}{*}{ 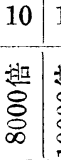 } & \multirow{2}{*}{ 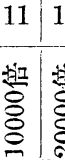 } & \multirow{2}{*}{\multicolumn{2}{|c|}{ 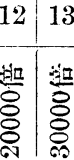 }} & \multirow{2}{*}{$\mid \begin{array}{l}14 \\
\frac{104}{8} \\
8 \\
8 \\
\vdots\end{array}$} & \multirow{2}{*}{ 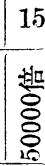 } \\
\hline & & & & & & & & & & & & & & & & & & & & \\
\hline \multirow{3}{*}{$\begin{array}{l}\text { 第 } \\
: 3\end{array}$} & \multirow[b]{3}{*}{0} & \multirow{5}{*}{$\begin{array}{l}\text { 試 } \\
\text { 㭲 } \\
\text { 家 } \\
\text { 鬼 } \\
\stackrel{\text { A }}{-}\end{array}$} & & & \multirow{5}{*}{$\begin{array}{l}\text { 隔日每 } \\
0.5 \% 5 \mathrm{cc} \\
\text { 宛 }\end{array}$} & & & $\mathrm{HH}$ & it & HI & H & $\mathrm{Ht}$ & HI & $\mathrm{iH}$ & $H$ & $\mathrm{H}$ & +1 & + & +1 & \pm \\
\hline & & & & 2150 & & $\mathrm{H}$ & & & $\mathrm{H}$ & HI & W & $H$ & $H$ & + & + & +1 & +1 & - & - & - \\
\hline & & & 第10號 & 1950 & & $H$ & & & HI & HI & Ht & HI & $H$ & $H$ & +1 & +1 & + & + & \pm & $\ldots$ \\
\hline \multirow{2}{*}{\multicolumn{2}{|c|}{ 免 }} & & & $\left.2^{\prime}\right) 50$ & & 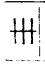 & & $H$ & HI & HI & HI & $\mathrm{H}$ & $\mathrm{HH}$ & $H$ & +1 & +1 & +1 & -1 & -1 & - \\
\hline & & & & & & & & & & $\mathrm{Ht}$ & H & $H$ & + & + & + & +1 & \pm & -1 & -1 & - \\
\hline 菌 & \multirow[t]{2}{*}{27} & \multirow{5}{*}{$\begin{array}{l}\text { 試 } \\
\text { 驗 } \\
\text { 家 } \\
\text { 兔 }\end{array}$} & & & \multirow{5}{*}{$\begin{array}{l}\text { 觕日每 } \\
1.0 \% 5 \mathrm{cc} \\
\text { 宛 }\end{array}$} & & & & HI & $H$ & $H$ & $H$ & + & + & \pm & -1 & -1 & -1 & - & 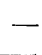 \\
\hline 戔 & & & & 2150 & & $m_{1}$ & & 1 & HI & $H$ & H & $H$ & + & + & + & + & -1 & -1 & - & - \\
\hline & 日 & & & 1950 & & HI & & $\mathrm{Ht}$ & $\mathrm{H}$ & HI & $\mathrm{HH}$ & $H$ & $H$ & $H$ & + & + & + & \pm & -1 & - \\
\hline & & & & & & $\mathrm{HI}$ & & & H & WI & $H$ & it & + & +1 & + & +1 & +1 & -1 & -1 & - \\
\hline & & & & & & & & & III & $\pi$ & & 111 & $H$ & + & + & + & -1 & - & - & \\
\hline
\end{tabular}




\begin{tabular}{|c|c|c|c|c|c|c|c|c|c|c|c|c|c|c|c|c|c|c|c|c|}
\hline & & & & & & & 2 & 3 & 4 & 5 & & & & & 10 & 11 & 12 & 13 & 14 & 15 \\
\hline & 月日 & & & 體 垂 & $\begin{array}{c}\text { 血圛 } \\
\text { 注:射量 }\end{array}$ & & 迦 & $\begin{array}{l}\text { 担 } \\
\infty \\
\infty\end{array}$ & $\frac{\text { 䞡 }}{\bar{\Xi}}$ & 垫 & 势 & 逝 & $\frac{110}{9}$ & 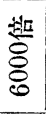 & 邆 & $\begin{array}{l}\text { 捛 } \\
\text { ○े } \\
\vdots\end{array}$ & 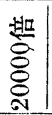 & $\begin{array}{l}\text { 斯 } \\
\vdots \\
0 \\
0 \\
0\end{array}$ & $\begin{array}{l}\text { Hang } \\
8 \\
\vdots \\
+1\end{array}$ & 逝 \\
\hline \multirow{5}{*}{ 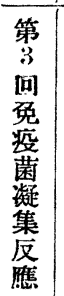 } & \multirow{4}{*}{$\begin{array}{c}5 \\
\text { 月 } \\
27\end{array}$} & \multirow[b]{2}{*}{ 對 } & & & \multirow{3}{*}{$\begin{array}{l}\text { 隔日每 } 0 . \\
9 \% \text { 食壏 }\end{array}$} & & & $H$ & $\mathrm{Ht}$ & $H$ & + & + & + & + & + & - & - & -1 & $1-1$ & - \\
\hline & & & & 2000 & & & 111 & $\pi$ & $\mathrm{H}$ & $H$ & $H$ & + & + & + & + & - & - & - & - & 一 \\
\hline & & 家 & & 2000 & & & $m$ & W & HI & $H$ & $H$ & + & + & + & + & + & - & -1 & - & - \\
\hline & & & & 2030 & \multirow[t]{2}{*}{ 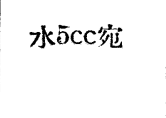 } & & & $\mathrm{H}$ & $H$ & $H$ & + & + & + & + & - & - & - & - & - & - \\
\hline & & & & & & & & & & & & 1 & + & + & + & \pm & - & -1 & -1 & - \\
\hline
\end{tabular}

第 2 回免疫二於テハ第4表ノ如ク，何レノ家鬼モ凝集價次第二增强シ，殊二第 2群二著シク逐二對照トノ間二殆ド差異ナキニ至レリ。

第5表ノ如ク第3回乔疫ニテハちらみんノ凝集素新生二及ボ入效果最モ顯著二 シテ，少量注射セル第 1 群二於テ八第 8 號、50000倍二, 第 10 號 240000 倍二テ弱 陽性二凝集シ，他ノ3頭ニアリテモ又20000倍ヨ下ラズ，即對照家鬼ノ8000-10 000 倍ナル $ル$ 比シ優 $=2-3$ 倍, 凝集價 示七り. 第2群入, 第13號家兔, ミ8000 倍(士)ナルモ，他ノ4頭、10000-20000倍ニシテ之刃遙二對照 7 凌駕セリ.

余入尚叙上實驗動物ノ內 10 頭 (3頭對照) ヨ選ビ，依然注射 7 連續シ免疫持續 期間拌二凝集價减退ノ模樣 7 觀察セリ。第6表及第7表二示スガ如ク，對照家鬼 、3回免疫後 10 日 ニシテ最高二達シ，其後 1 週間 $=800-10000$ 倍 3 y $6000-800$ 0 倍二, 即最高凝集價ノ5分ノ 1 失フ二過ギザルニ, 第 1 群ノ家鬼ニアリテハ免 疫偪ノ减弱實二著ク其ノ過半 スルニ家鬼 7 免疫シツ、ちらみんヨ少量連續注射スル時ハ, 凝集價八對照二比 シ增强甚シキモ，一定時日ノ後二八其ノ减弱却テ速カナリ。入大量注射スレバ 最初ソノ上昇迤々タルモ, 對照 $コ$ 速カ二極期二到達シ, 後等激二降下スルモ ノナリ.

第 6 表

\begin{tabular}{|c|c|c|c|c|c|c|c|c|c|c|}
\hline \multirow{3}{*}{ 檢 查 日 } & 注 射 量 & \multicolumn{9}{|c|}{$0.5 \%$ ち 万み 溶液 $5 \mathrm{cc}$ 宛隔日注 射 } \\
\hline & 家鬼番號 & 第 & 8 & 號 & 第 9 號 & 第 10 & & 第 & 11 & 號 \\
\hline & $\begin{array}{l}\text { 菌葆 } \\
\text { 注射 }\end{array}$ & 擬集價 & $\mid \begin{array}{l}\text { 赤血球 } \\
\text { (位) }\end{array}$ & $\begin{array}{c}\text { 血色素 } \\
(\%)\end{array}$ & 凝集顀球系䋰色 & 凝集價球 & 血血色 & 凝集嘼 & 赤血球 & 血色素 \\
\hline 試 驗 前 & 第1回 & 20 & 540 & & \begin{tabular}{l|l|l|}
40 & 612 & 80
\end{tabular} & 30563 & 380 & 20 & 630 & 79 \\
\hline
\end{tabular}


叶原留吉述

$(1545)$

\begin{tabular}{|c|c|c|c|c|c|c|c|c|c|c|c|c|c|c|}
\hline \multirow{3}{*}{ 檢賚 日 } & \multicolumn{13}{|c|}{ 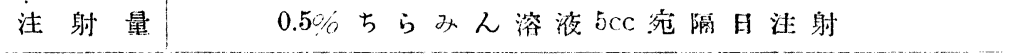 } & \multirow[b]{2}{*}{ 號 } \\
\hline & \multicolumn{2}{|c|}{ 家鬼番號 } & 第 & 8 & 號 & 第 & 9 號 & & 第 & 10 & 號 & 第 & 11 & \\
\hline & $\begin{array}{l}\text { 注射 } \\
\text { [泪數 }\end{array}$ & $\begin{array}{l}\text { 菌液 } \\
\text { 注射 }\end{array}$ & \multicolumn{6}{|c|}{ 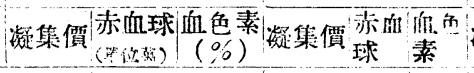 } & 擬集價 & 珪血 & 血色 & \multicolumn{3}{|c|}{ 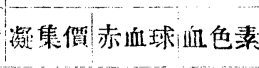 } \\
\hline $\begin{array}{l}\text { 注射開始後 } \\
\text { 第 } 3 \text { 日 }\end{array}$ & 1间 & & 1 & 512 & 70 & & 572 & 77 & & 540 & 82 & & 610 & 74 \\
\hline 第 7 口 & 3 问 & 第2回 & $\begin{array}{c}10000 \\
\pm\end{array}$ & 5280 & 71 & 5000 & 545 & 77 & 6000 & 561 & 70 & 6000 & $61 \tilde{1}$ & 75 \\
\hline 第 10 日 & 5 回 & & & 450 & 64 & & 502 & 73 & & 523 & 70 & & 548 & 72 \\
\hline 第 14 日 & 7 回 & 第3回 & 30000 & 400 & 60 & 8000 & 550 & 61 & 20000 & 501 & 66 & $\begin{array}{c}10000 \\
t:\end{array}$ & 520 & 70 \\
\hline 第 17 日 & S[回 & & & 523 & 73 & & 574 & 68 & & 568 & 76 & & 582 & 82 \\
\hline 第 21 月 & 10回 & & $\begin{array}{l}50000 \\
\pm\end{array}$ & 516 & 70 & 20000 & 610 & 71 & $\begin{array}{c}400(10 \\
\pm\end{array}$ & 550 & 75 & 20000 & 662 & 82 \\
\hline 第 24 日 & 12 回 & & 50000 & 510 & 77 & 10000 & 594 & 76 & $\begin{array}{c}40000 \\
\pm\end{array}$ & 576 & 82 & 30000 & 570 & 91 \\
\hline 第 28 日 & 14回 & & $\begin{array}{c}30000 \\
\pm\end{array}$ & 537 & 76 & 10000 & 576 & 80 & 30000 & 570 & 88 & 10000 & 532 & 88 \\
\hline 第 31 H & 15回 & & $\begin{array}{l}30000 \\
\pm\end{array}$ & 588 & 76 & $\begin{array}{c}10000 \\
\pm\end{array}$ & 620 & 82 & $\begin{array}{c}20000 \\
\pm\end{array}$ & 570 & 87 & 10000 & 540 & 48 \\
\hline
\end{tabular}

第 7 表

\begin{tabular}{|c|c|c|c|c|c|c|c|c|c|c|c|c|c|c|}
\hline \multirow{3}{*}{ 檢 查 日 } & \multirow{2}{*}{\multicolumn{2}{|c|}{$\frac{\text { 注 射 量 }}{\text { 家黾番號 }}$}} & \multicolumn{9}{|c|}{ 1.0\%ちらみん液液う̄cc宛隔山注射 } & \multicolumn{2}{|l|}{ 對 } & 照 \\
\hline & & & 第 & 14 & 號 & 第 1 & 15 号 & 蹠 & 第 & 16 & 號 & 第 19 號 & 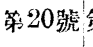 & 第21號 \\
\hline & $\begin{array}{l}\text { 注射 } \\
\text { 回數 }\end{array}$ & $\begin{array}{l}\text { 菌液 } \\
\text { 注射 }\end{array}$ & 疑権價 & $\begin{array}{l}\text { 赤血球 } \\
(\text { 涪位萬) }\end{array}$ & 血色素 & 疑本價王 & 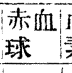 & 笙色 & 凝集價 & 浾血 & 欰色 & 㠜焦保 & 凝策 1 & 凝集價 \\
\hline 試 噞 前 & & 第1回 & 20 & 55 & 77 & 20 & 620 & 75 & 30 & $0 \quad 580$ & 80 & 40 & 30 & 40 \\
\hline 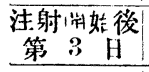 & 1 回 & & & 479 & 75 & & 528 & 69 & & 464 & 75 & & & \\
\hline 第 7 日 & 3回 & aii 2[ & 800 & 439 & 80 & $\begin{array}{l}2000 \\
\pm 1\end{array}$ & 447 & 58 & $\begin{array}{l}1000 \\
\pm\end{array}$ & \begin{tabular}{|l|}
498 \\
\end{tabular} & 63 & 2000 & $\begin{array}{l}2000 \\
\pm\end{array}$ & 3000 \\
\hline 第 10 日 & 5 回 & & & 407 & 67 & & 490 & 52 & & 360 & 63 & & & \\
\hline 第 14 日 & $7[$ [ $]$ & 第3回 & 6000 & 516 & 62 & $6 \mathrm{COO}$ & 490 & 59 & 5000 & $0 \mid 515$ & 55 & $\begin{array}{l}4000 \\
\pm\end{array}$ & 4000 & 6000 \\
\hline 第 17 日 & 8回 & & & 502 & 75 & & 521 & 56 & & 492 & 67 & & & \\
\hline 第 21 日 & 10回 & & 10000 & 540 & 76 & $\begin{array}{c}30000 \\
\pm\end{array}$ & 510 & 62 & 20000 & $0 \quad 518$ & 82 & 8000 & 8000 & 10000 \\
\hline 第 $24 \mathrm{H}$ & 12 回 & & 8000 & 594 & 85 & $\begin{array}{c}30000 \\
\pm\end{array}$ & 580 & 70 & 10000 & 0645 & 80 & 8000 & 10000 & 10000 \\
\hline 第 28 日 & 14回 & & 6000 & 575 & 81 & 10000 & 623 & 73 & $\begin{array}{c}20000 \\
\pm\end{array}$ & $\begin{array}{r}0 \\
\quad 620 \\
\end{array}$ & 84 & 6000 & 8000 & $\begin{array}{l}8000 \\
\pm\end{array}$ \\
\hline 第 31 日 & 15回 & & 6000 & 570 & 78 & $\begin{array}{l}1000 \\
\pm\end{array}$ & 604 & 72 & 10000 & \begin{tabular}{ll|}
0 & 672 \\
\end{tabular} & 87 & 6000 & 8000 & 8000 \\
\hline
\end{tabular}

予八本實驗二使用セル家鬼二就 $\neq 1$ 週 2 回, 赤血球數及血色素量 $ᄏ$ 檢セり. 又 對照動物二於テ, 即菌液注射ノミニョリテハ, 赤血球, 血色素ノ何レ二就キテ モ劃一的ノ量的影響ヨ認メザリキ，サレバ對照ハ凝集價ノミヨ表示スルコトト 
ヒリ.

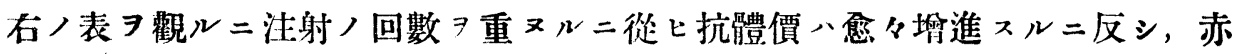

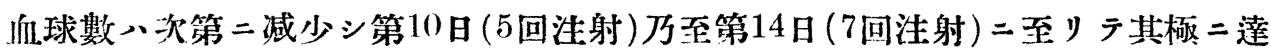

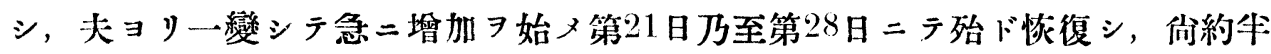

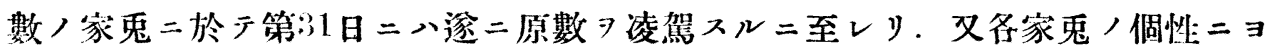
リ相賞差異ナキニ非ザルモ，大體二於テ大量注射セシモノ八少量注射ノモノ二 比シ貧血，度速》二, 且强ク, 其ノ恢復モ又多少僬延スルモノナリ。

即, 乔疫凝集素啋生、第2群ノ如キ貧血, 强度ナルモノ二於テ最初少シク阴 止サル、ノミニテ一般二增强シ，注射開始後 2 週閒 $=$ テ赤血球再生機能㭗々旺 盛トナルニ係ラズ，一旦極期二到達セシ凝集檟 却テ速カニ减弱スルモノナ y.

\section{第 3 章 皖生免疫疑集素 填合}

實驗動物・何レモちふす菌 集價ノ略ボ一定セルラ確メ，ちらみん溶液ノ各量 7 注射シ血清中ノ凝集價ガ如 何二戀動スルャ二就キ實驗セり。ナホ本實驗二先チ, おふす免疫血清 試驗管二分天，ソノ1本二 $1.0 \%$ ちらみん溶液 $\exists$ 加へ，他，1本二八生理的食盍 水 7 混 $シ 37$ 度二置クコト2時間, 各液二就キちふす菌二對スル凝集價 二两者間二殆ド差黑ナカリキ，即ちらみん溶液”血清中，免疫凝集素二邺シ直 接認么可キ影響ヨ及ボサズ.

余ハ先ヅ4頭，免疫家鬼 $=1.0 \%$ 万みん溶液 $10.0 \mathrm{cc}$ 宛 7 靜脈內二洼射シ一定 時間每 $=1$ 日數回採血シンノ凝集價 $ᄏ$ 檢セリ.

第 8 表 1 注射, $1.0 \%$ 溶液 $10.0 \mathrm{cc} 1$ 回

\begin{tabular}{|c|c|c|c|c|c|c|c|c|c|c|c|c|c|c|c|c|}
\hline \multirow{2}{*}{$\frac{\text { 家鬼番號 }}{\text { 試驗管番號 }}$} & \multicolumn{3}{|c|}{ 第 } & \multicolumn{2}{|c|}{51} & \multicolumn{3}{|c|}{ 號 } & \multicolumn{3}{|c|}{ 第 } & \multicolumn{2}{|c|}{53} & \multicolumn{3}{|c|}{ 號 } \\
\hline & 1 & 2 & 3 & 4 & 5 & 6 & 7 & 8 & 1 & 2 & 3 & 4 & 5 & 6 & 7 & 8 \\
\hline $\begin{array}{l}\text { 血婊稀 } \\
\text { 糀倍数 } \\
\text { 探血 } \\
\text { 時間 }\end{array}$ & 800 & 1000 & 1500 & 2000 & 3000 & 4000 & 6000 & 8000 & 800 & 1000 & 1500 & 2000 & 3000 & 4000 & 6000 & 80010 \\
\hline 試 駗 前 & $H$ & $H$ & + & + & + & + & \pm & - & H & $H$ & $H$ & + & + & + & \pm & - \\
\hline 1 時 間 & $t+$ & + & + & + & \pm & - & - & $\ldots$ & + & + & + & + & \pm & - & $\cdots$ & - \\
\hline
\end{tabular}


III

\begin{tabular}{|c|c|c|c|c|c|c|c|c|c|c|c|c|c|c|c|c|}
\hline \multirow{2}{*}{$\begin{array}{c}\text { 象黾番號 } \\
\text { 試驗管番號 }\end{array}$} & \multicolumn{3}{|c|}{ 第 } & \multicolumn{2}{|c|}{51} & \multicolumn{3}{|c|}{ 號 } & \multicolumn{3}{|c|}{ 第 } & \multicolumn{2}{|c|}{53} & \multicolumn{3}{|c|}{ 號 } \\
\hline & 1 & 2 & 3 & 4 & $\overline{5}$ & 6 & 7 & 8 & 1 & 2 & 3 & 4 & 5 & 6 & 7 & 8 \\
\hline $\begin{array}{c}\text { 血渄稀 } \\
\text { 探血 } \\
\text { 時閔 }\end{array}$ & 800 & 1000 & 1500 & 2000 & 3000 & 4000 & 6000 & 8000 & 800 & 1000 & 1500 & 2000 & 3000 & 4000 & 6000 & 8000 \\
\hline ; 時 閑 & $H$ & $H$ & tí & + & + & - & - & - & $H$ & + & + & + & \pm & - & - & - \\
\hline ； 時 問 & Ht & $H$ & + & + & + & $\ldots$ & $\ldots$ & - & $H$ & + & + & -+ & + & - & - & - \\
\hline 9 時 间 & $H$ & $H$ & + & + & \pm & $\cdots$ & - & - & it & + & + & + & + & + & - & - \\
\hline 24 特 問 & $H$ & H & $H$ & + & + & $:$ & $\cdots$ & - & H & $H$ & $H$ & + & + & + & + & - \\
\hline $\mathrm{H}$ & & H & H & + & +1 & + & + & - & $H$ & $H$ & + & + & +1 & + & \pm & $1-$ \\
\hline
\end{tabular}

第 8 表, 2 注射, 同前

\begin{tabular}{|c|c|c|c|c|c|c|c|c|c|c|c|c|c|c|c|c|}
\hline \multirow{2}{*}{\begin{tabular}{c|} 
家兔番號 \\
試驗管番號
\end{tabular}} & \multirow{2}{*}{1} & \multicolumn{2}{|c|}{ 第 } & \multicolumn{2}{|c|}{54} & \multicolumn{3}{|c|}{ 號 } & \multicolumn{3}{|c|}{ 第 } & \multicolumn{2}{|c|}{55} & \multicolumn{3}{|c|}{ 號 } \\
\hline & & 2 & 3 & 4 & 5 & 6 & 7 & 8 & 1 & 2 & 3 & 4 & 5 & 6 & 7 & 8 \\
\hline $\begin{array}{c}\text { 血要稀 } \\
\text { 釋倍数 } \\
\text { 時血間 }\end{array}$ & 800 & 1000 & 1500 & 2000 & 3000 & 4000 & 6000 & 8000 & 800 & 100 & 1500 & 2000 & 3000 & 4000 & 6000 & 8000 \\
\hline 試 驗 前 & $H$ & it & + & + & + & + & - & - & H & $H$ & $H$ & + & + & + & + & - \\
\hline 注射後閣 & + & + & + & + & \pm & - & - & - & + & + & + & \pm & - & - & - & $\ldots$ \\
\hline 8 時 闆 & + & + & + & \pm & - & $\cdots$ & - & - & $H$ & + & + & + & + & - & - & - \\
\hline 6 时 & $H$ & ti & + & + & + & - & - & - & $H$ & + & + & + & + & - & - & - \\
\hline 9 時 間 & $H$ & $H$ & + & + & + & - & - & - & $H$ & $H$ & + & + & + & \pm & - & - \\
\hline 24 喑 間 & H & $H$ & $H$ & + & + & + & - & - & H & H & $H$ & $H$ & + & + & + & \pm \\
\hline 日 & H & $H$ & + & + & + & + & - & -- & H & H & + & + & + & + & \pm & - \\
\hline
\end{tabular}

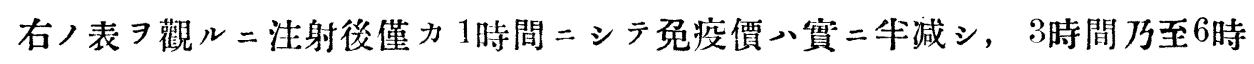

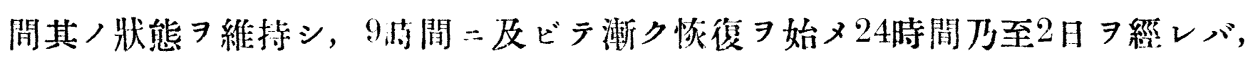
注射前 ニ比シソノ沗集價僅カ二高キモノアリ。

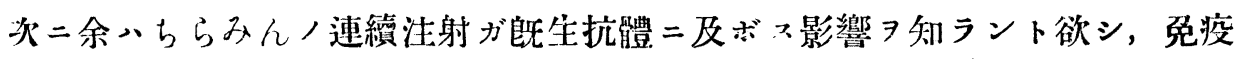

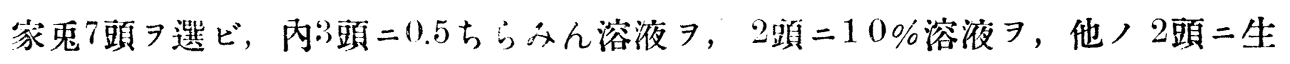

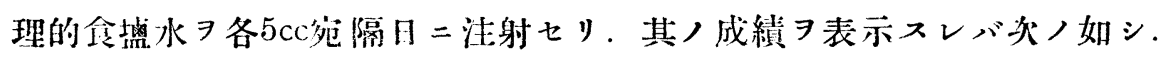




\begin{tabular}{|c|c|c|c|c|c|c|c|c|c|c|c|c|c|}
\hline \multirow{3}{*}{ 檢杰 H } & \multirow{3}{*}{$\begin{array}{l}\text { 注射量 } \\
\text { 家鬼 } \\
\text { 番號 } \\
\text { 注射 } \\
\text { 回数 }\end{array}$} & \multicolumn{6}{|c|}{ 0.5\%ちらみみ溶液5cc犹陷日注射 } & \multicolumn{4}{|c|}{$\begin{array}{l}1.0 \% 55 \text { 小溶液 } 5 \mathrm{Cc} \\
\text { 宛隔日注射 }\end{array}$} & \multirow{2}{*}{$\begin{array}{c}\text { 對 } \\
\text { 第象22號 }\end{array}$} & \multirow{3}{*}{$\begin{array}{c}\text { 照 } \\
\text { 第23频 } \\
\text { 凝集價 }\end{array}$} \\
\hline & & 第 63 & 號 & 第 64 & 號 & 第 65 & 號 & 第 66 & 號 & 筑 67 & 暍 & & \\
\hline & & 擬算價郝 & $\begin{array}{l}\text { 系血球! } \\
\text { 單位萧) }\end{array}$ & \multicolumn{2}{|c|}{ 凝集價 赫血球 } & 㠜集僄 & 赤血球 & \multicolumn{2}{|c|}{ 筑集偠赤血球: } & \multicolumn{2}{|c|}{ 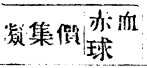 } & 绕集貸 & \\
\hline 試 驗 前 & & 8000 & 582 & 5000 & 608 & 6000 & 633 & 4000 & 650 & $\begin{array}{l}5000 \\
\pm\end{array}$ & 583 & 4000 & 6000 \\
\hline $\begin{array}{l}\text { 注射後 } \\
\text { 第 } 3 \text { 日 }\end{array}$ & 1回 & 8000 & 560 & 5000 & 572 & 6000 & 592 & 5000 & 518 & 5000 & 501 & 4000 & 5000 \\
\hline 第 7 日 & 3 可 & 7000 & 567 & 6000 & 535 & 7000 & 590 & $\begin{array}{l}4000 \\
\pm\end{array}$ & 470 & 4000 & 449 & $\begin{array}{l}4000 \\
\pm\end{array}$ & 5000 \\
\hline 第 10 日 & 5 回 & 7000 & 521 & $\begin{array}{l}5000 \\
\pm\end{array}$ & 502 & 6000 & 541 & $30 \mathrm{co}$ & 481 & 4000 & 427 & 4000 & $\begin{array}{l}5000 \\
\pm\end{array}$ \\
\hline 第 14 日 & 7回 & 6000 & 505 & 5000 & 563 & $\begin{array}{l}5000 \\
\pm\end{array}$ & 527 & 3000 & 488 & 2000 & 536 & 3000 & $\begin{array}{l}4000 \\
\pm\end{array}$ \\
\hline 第 21 日 & 10 简 & 7000 & 560 & 4000 & 592 & 5000 & 590 & 3000 & 560 & 3000 & 530 & 2000 & 3000 \\
\hline 第 28 日 & 14回 & $\begin{array}{l}6000 \\
\pm\end{array}$ & 593 & 3000 & 587 & 4000 & 616 & $\begin{array}{l}2000 \\
\pm\end{array}$ & 599 & 2000 & 577 & 2000 & $\begin{array}{l}3000 \\
\pm\end{array}$ \\
\hline
\end{tabular}

即, 二三八家兔二於テッ1回乃至3回泩射後凝集價少シク增强スルモノナキ二 非ルモ，一般二次第二减弱シ其ノ程度二於テ對照例トノ間二殆ド曾異 ザリキ。

最後二余ハ大量注射ノ影響 $习$ 檢センガ雼, 凝集價高キ3頙ノ免疫家鬼ニ1.0ち らみん液 $10 \mathrm{cc}$ 宛, 朝夕2回3日間連䋶注射セリ。

第 10 表

\begin{tabular}{|c|c|c|c|c|c|c|c|}
\hline 注 射 & & \multicolumn{6}{|c|}{$1.0 \%$ ちらみん溶液 $10 \mathrm{cc}$ 宛 1 日 2 回 3 日閑注射 } \\
\hline 家 兔 番 & 號 & 第 & 號 & 第 & 號 & 第 & 號 \\
\hline 查 & 日 & 凝 集 價 & $\begin{array}{l}\text { 洂 血 球 } \\
\text { (單位萬) }\end{array}$ & 凝 集 價 & 赤 血 球 & 凝 集 傮 & 赤 血 球 \\
\hline 試 驗 & 前 & 10000 & 591 & 6000 & 605 & 7000 & $58:$ \\
\hline $\begin{array}{c}\text { 最紷注射後 } \\
\text { 第 } 2 \\
\end{array}$ & 日 & 3000 & 461 & 4000 & 472 & 3000 & 491 \\
\hline 第 3 & 日 & $5000( \pm)$ & 450 & $3000( \pm)$ & 430 & $3000( \pm)$ & 455 \\
\hline 第 5 & $\mathrm{H}$ & 5000 & 407 & 2000 & 497 & 2000 & 392 \\
\hline 第 10 & 日 & $4000( \pm)$ & 422 & 3000 & 418 & 4000 & 414 \\
\hline 15 & 日 & 2000 & 536 & 2000 & 515 & 2000 & 588 \\
\hline 第 25 & 日 & $2000 \pm \pm)$ & 577 & 1000 & 601 & 2000 & 603 \\
\hline
\end{tabular}

其ノ結果八第 10 表 $=$ 觀 $カ ゙$ 如ク，注射終了ノ翌日二於テ第 69 號八試驗前ノ 60 00倍ヨリ4000倍二，他ノ2頭、10000倍及7000倍ヨy何レモ3000倍二，即其，疑 集價ノ3分ノ 1 乃至3分ノ 2 减ズ. 而レドモ其ノ後・减退ノ度比較的緩慢ニシテ 
田原留吉迅

(1549)

對照家鬼ハソレニ殆ド異ラズ.

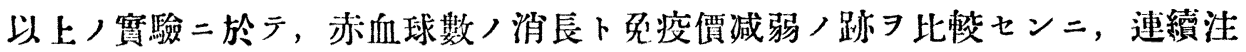

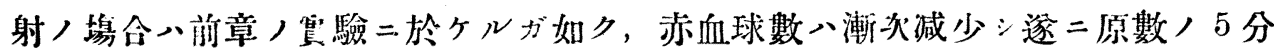
ノ 1 消失ハルニ至ルモ，凝集價八對照卜，間二殆ド羑異习認メズ，们極メラ 大量洁射スレバ免度價、激减シ，赤血球又减少スルも，シカク急激ナラズ，而 シテ何レノ㷪合ニアリテモ一定時日ノ後, 赤血球再生機能入旺盛トシリ貧血八 速カニ恢復サル、モ凝集價入再ビ上列スルコトナシ.

\section{總括}

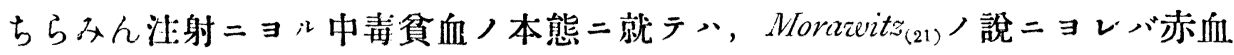
球八陝義ノ溶血 $コ$ 起スニ非ズシテ，ちらみんニヨリ先ヅ或程度二損傷セラレ而

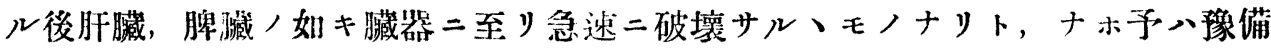
實驗二於テ，ちらみれノ $1.0 \%$ 溶液ガ家鬼赤血球 トヨ認メタリ．即ちらみん八赤血球二對スル態度ハ他ノ溶血毒ト著シク其八趣

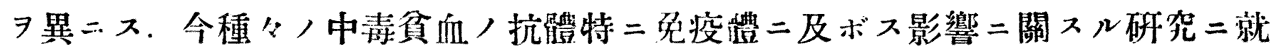
キ, 之ヨ文献二徵スル

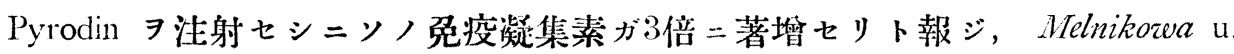
$W_{\text {elsillowar(22) }}$ Phenylhydrazin 及 Hydroxlamin 八注射が家鬼二於ラ却ラちふす 菌二對スル免疫凝集價 7 低下七シト報ジ，最近柏原(23) 、Phengllhydrazin注射二 ヨリ豫入强度,貧血二陷リシ家鬼一對照二比シ㣻疫體新生ノ度極〉テ徐々二, 而モ其最高免疫價モ甚ダ微弱ナリト，ナホ同劑注射が既生免疫體二對シテモ著 クッ>效果习减弱セシムルト報告セり, 又西谷(21) 、Hydroxylamin 中素貧血家 鬼二於㣻疫體產生能力习檢七シ二對照例二比シ稍低下セルコトヨ認メタ.リ.

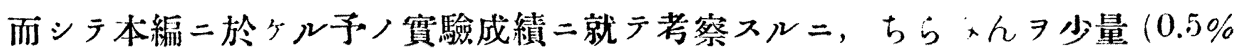
jcc 隔日)宛家鬼二速續注射スル時》赤血球入次第二减少スル二係ラズ正常凝集

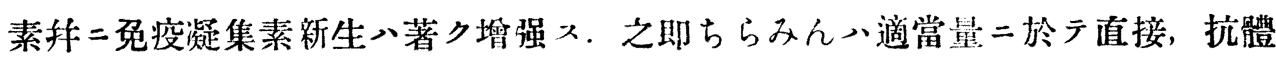
產生度地ノ細胞 7 刺载シテ其機能 7 增监七シムルモノナル可ク, 又同放注射二 $\exists り$ 比較的慢性二起》シ貧血八可成强度二達スルモ, 抗體產生二對シテ殆ド影 響ナキ事ヨ知ル可シ。ナホちらみん八同量注射ガ既生免疫凝集素二對シテノミ 獨り何等認么可キ效果ナキャ興味アル事實ニシテ, 即數回ノ免疫ニョリラ極度

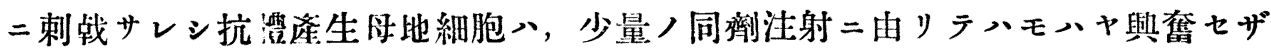
ル篇ナラン, 又ちらみんノ極メラ大量 $(1.0 \% 10 \mathrm{cc}$ 宛6回) 7 免疫家兔二注射セル

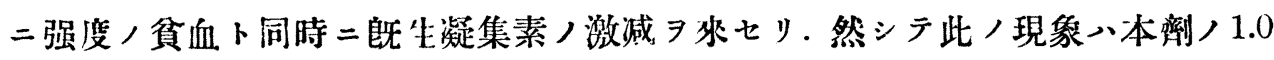
\%溶液10.()cc1回ノ注射ニョリラモ觀ラル、モノナルガ，前者二ラ、凝集價、 
再ビ.上昇セザルニ反シ，後者‥注射绕數時問乃至 24 時間二テ佲ド回徣スルモ， ナリ。而シテちらみん溶液ガ淔接血清中ノ凝集素习障害七ザル从予ノ预備賽驗

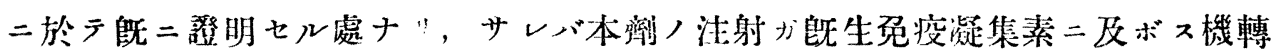
八, らみんガ直接抗體產生址地二日害二作用シ，抗體ガ血液中二移行シ得ザ ルモノト解人可キナリ。ナホ其ノ障害ノ輕微ナル時ハ、前述セルガ如ク數時間 ニシテ扰體產生目地ハソ, 機能习恢復シ得ルモノナル可シ。

ちらみんニョル中毒貧血ハソノ注射量ニョリ僬速アルモ一定時 $\mathrm{H}$ ノ後二八極

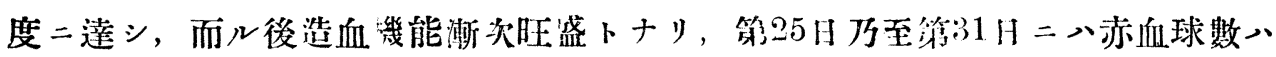
殆ド注射前ノ狀態二復セリ，然ル二同劑/注射二由リ其ノ新生 7 兀進サレシ凝

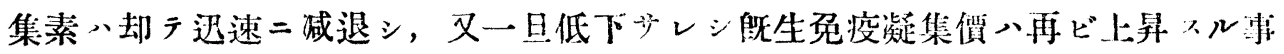
ナシ, 即, 造血臟器, 興奮モ抗體價 7 增强スルコトナシ.

ちらみんノ藥物學的作用二關シテハ學者ニヨリ唄說ナキニ非ザルモ大體わご れなりんノ夫二類似セリトハ前述七ルトコロナリ。而シテ㐓ごれなりんノ抗體

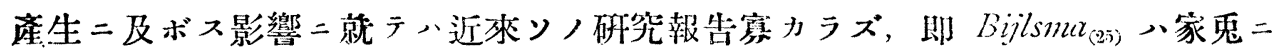
於テあごれなりんノ注射、乔疫凝集價及溶血價二龁シテ著キ效果ナシト報ジ，

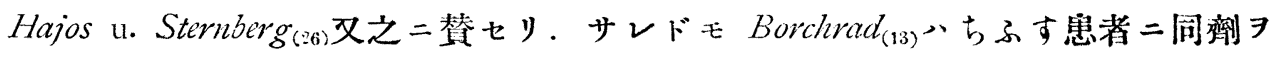

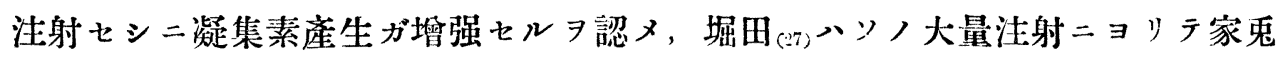
二於ケル既生苼疫價…時上昇七ルモ後直千二降下七り!報ジ，永橋(18)八家束 二同劑ノ少量

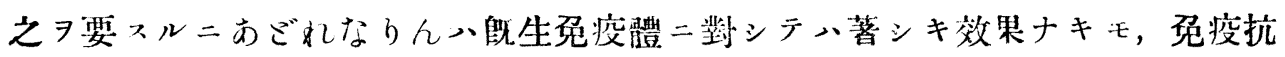
體產生二就テハ之ヨ助長七シムルモ, 如ク, 而シテちらみんヨ以テセル予, 實驗成績ト比䡴スル二稍類似セリ．即，ちらみん八其ノ藥物學的作用二於ヶル ガ如ク免投學的作用二就テモ又かごれなりんトノ間二其通點

\section{結諡}

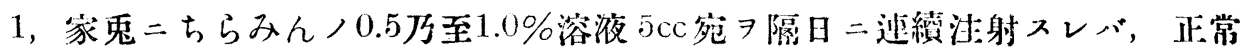
凝集價 素二對シテハ殆ド認ム可キ影響ヨ及サズ.

2, ちらみんノ多量 (1.0\%溶液 $10 \mathrm{cc}$ 宛6回) 7 㣻疫家鬼二注射入レバ既生凝集 價八著ク下降ス。

3，ちらみんノ少量ノ連續洼射ニョリテ徐々二惹起七ラレタル貧血入，凝集

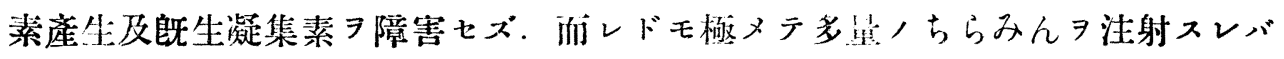
家鬼入速力二强度ノ貧血二陷ルト同時二既生凝集價、减弱入。

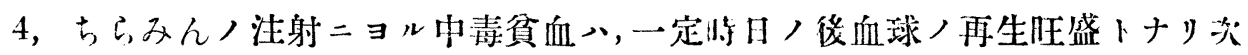
第二治瘾スルモ,一旦低下七シ免疫凝集價ハ再ビ上昇スルコトナシ・(文献後出) 